\title{
Physical characteristics of soils in landslide areas of Cadac-an Watershed in Leyte, Philippines
}

\author{
Jorge P. Cabelin, Jr. ${ }^{1 *}$ and Beatriz C. Jadina ${ }^{2}$
}

\begin{abstract}
Landslides have become very frequent in Leyte which justifies the need for soil assessment and characterization of the landslide-prone areas in the province. This study assessed the physical characteristics of soils from the landslide areas in Cadac-an watershed in Leyte, Philippines. Landslide cuts located in the central highlands of Cadac-an watershed were used as representative profiles in this study. These were examined, characterized and sampled for the analyses of soil physical properties which include particle size distribution (Pipette method), bulk density (Paraffin-clod method), particle density (Pycnometer method), porosity, total soil wet density, water holding capacity and field capacity (Gravimetric method), saturated hydraulic conductivity (Constant head method), liquid limit and plastic index. Generally, soils from the landslide areas in Cadac-an watershed had a sandy loam to clay loam to clayey texture, low bulk density, low particle density, high porosity, moderate total soil wet density, moderate to high water holding capacity, low to moderate field capacity, moderately high to high saturated hydraulic conductivity, moderate liquid limit and low plastic index. Based on the above characteristics, the soils are susceptible to landslide occurrence thus it is highly recommended to conduct constant assessment and monitoring of the area.
\end{abstract}

Keywords: landslides, soil physical characteristics, watershed, Leyte, Philippines

\section{INTRODUCTION}

One of the disaster prone areas in the world is the Philippines. It is characterized by the presence of the active Philippine Fault Zone which passes at the center of Leyte cordillera and is located in the dangerous zone known as the Ring of Fire, where a large number of earthquakes, volcanic eruptions and other disasters often occur. One of the most alarming disasters occurring in the country is landslides which have become frequent and are commonly occurring in watershed areas, affecting their functions and services (Jadina 2013).

\footnotetext{
${ }^{1}$ Department of Agriculture College of Agriculture and Natural Resources Bohol Island State University

${ }^{2}$ Department of Soil Science College of Agriculture and Food Science Visayas State University
}

\footnotetext{
*Corresponding Author. Address: Department of Agriculture College of Agriculture and Natural Resources Bohol Island State University; Email: cabelinjorge@gmail.com
} 
Few researches have been done about landslides in the Philippine watersheds, thus little is known about their causes and impacts. With these, mountainous areas of Leyte Island are increasingly experiencing catastrophic landslides along with Southern Leyte and recorded the worst landslide occurrences. In November 1991, a landslide incident occurred in Ormoc City, Leyte and claimed 5,000 lives. Furthermore, massive landslides occurred at Panaon Island (December 2003) and St. Bernard (February 2006), both located in Southern Leyte which claimed 200 and more than 1,000 lives, respectively (Jadina 2013). Landslides pose a major threat not only on the lives of the people but also on the environment, particularly on watershed areas. This catastrophic event increasingly causes watershed degradation.

A watershed includes resources which are multifunctional like vegetation, soil, water, air, people and other organisms living in the environment. It is not simply a hydrological unit but also a socio-political-ecological entity which plays a crucial role in determining food, social and economic security and provides life services to people (Wani et al 2008). However, through time, watersheds are increasingly degraded due to anthropogenic issues and problems like improper human practices causing chemical and biological pollution and overexploitation of resources, resulting to damage and destruction. Moreover, natural factors like rainfall (amount, intensity, variability, distribution, \& frequency), topography and soil (texture, structure, depth, moisture, infiltration rate, etc) also contribute to watershed degradation. These factors play an important role in the scope and scale of watershed degradation process. Due to these factors, natural processes such as soil erosion and landslides occur within the watershed, affecting its functions. Degradation of watershed resources at an alarming rate may jeopardize the food security besides posing a major threat to the existence of fragile ecosystems over a period of time (Walia et al 2010).

Soil erosion and landslides are considered as two of the most serious environmental problems in the world today which contribute to watershed degradation. Slopes and upland areas which were once covered with forest and vegetation have been heavily degraded due to land conversion to agriculture, triggering soil erosion and landslide (Rasul \& Thapa 2007). The presence of faults and shallow soil layers with an increasing intensity and frequency of rainfall events have caused severe and frequent landslides in the Shenmu watershed and Ta-Chia river watershed of Central Taiwan and Shivkola watershed of West Bengal (Chen et al 2014, Tan et al 2008, Mandal \& Maiti 2013). According to Jadina (2013), one of the important factors influencing landslide occurrences in Southern Leyte is soil properties such as particle size distribution, activity factor, liquid limit, water holding and field capacities and bulk densities.

Soil physical properties such as particle size distribution influence slope stability because it affects the moisture capacity and the rate of water movement in the soil. Soils in steep slope areas with high water retention capacity and low bulk density may result in landslides due to the combined weight of water and soil materials (Jadina 2013). In addition, the swelling properties of clay and the infiltration rate of water down the profile also play a part in triggering landslides.

Today, among the greatest constraints to sustainable development in our time is the degradation of watersheds and its resources. With increasing effects brought by these catastrophic landslides, a thorough study is needed to provide an efficient and effective measure to mitigate landslide occurrences in watershed areas. Thus, 
Physical characteristics of soils in landslide areas

this study aimed to assess the physical characteristics of soils from the landslide areas in the Cadac-an watershed in Leyte, Philippines.

\section{MATERIALS AND METHODS}

\section{The Study Sites}

The study area was the Cadac-an watershed which covers parts of the municipalities of Abuyog, Mahaplag and Javier in Leyte, Philippines. Each municipality was represented by either a landslide cut or a tension crack for soil profile examination and sampling for laboratory analyses.

\section{Soil Profile Characterization, Sampling and Preparation of Soil}

Standard procedures for soil description (FAO 2006) were used for the determination of soil profile characteristics which include layer designation and depth of soil layers.

Soil samples were collected from the lower to uppermost horizon. A sample of about three $\mathrm{kg}$ from each horizon was collected and placed in labeled bags. The samples were air dried, pulverized and sieved through a $2 \mathrm{~mm}$ screen prior to physical analyses.

\section{Soil Physical Properties Determination}

Particle size distribution was determined through pipette method (ISRIC 1995). Bulk density (BD) determination was done by paraffin-clod method using undisturbed bulk soil samples, while particle density (PD) was determined by pycnometer method (Klute 1986). Soil porosity was calculated using the computed values of bulk and particle densities, following the formula:

$$
\text { Porosity }(\%)=1-(\mathrm{BD} / \mathrm{PD}) \times 100
$$

Total soil wet density was calculated using the values of bulk density, porosity and the constant water density (DW) value of $1.0 \mathrm{~g} \mathrm{~cm}^{-3}$ by formula:

Total soil wet density $=B D+P(D W)$

Water holding and field capacities and saturated hydraulic capacity were determined by gravimetric method and constant head method, respectively, as described by Klute (1986). Liquid limit and plastic index were determined using the following pedotransfer equations by National Soil Survey Center (1995):

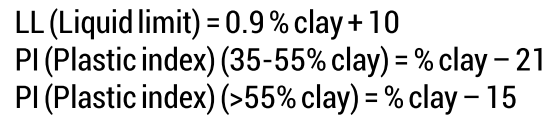


Cabelin \& Jadina

\section{RESULTS AND DISCUSSION}

\section{Description of the Study Site}

The study site, Cadac-an watershed, has a total land area of $65,957.5$ ha and is located at the central highlands of Leyte, Philippines. It is bounded by $10^{\circ} 26^{\prime}$ to $10^{\circ} 48^{\prime}$ north latitude and $124^{\circ} 50^{\prime}$ to $125^{\circ} 7^{\prime}$ east longitude (Figure 1). Located in the east are the municipalities of Baybay and Inopacan, on the west are Abuyog and Silago, on the north are Javier and MacArthur and on the south are Mahaplag and Sogod. Cadac-an watershed covers most parts of Javier, Abuyog, and Mahaplag municipalities where soil profiles were located.

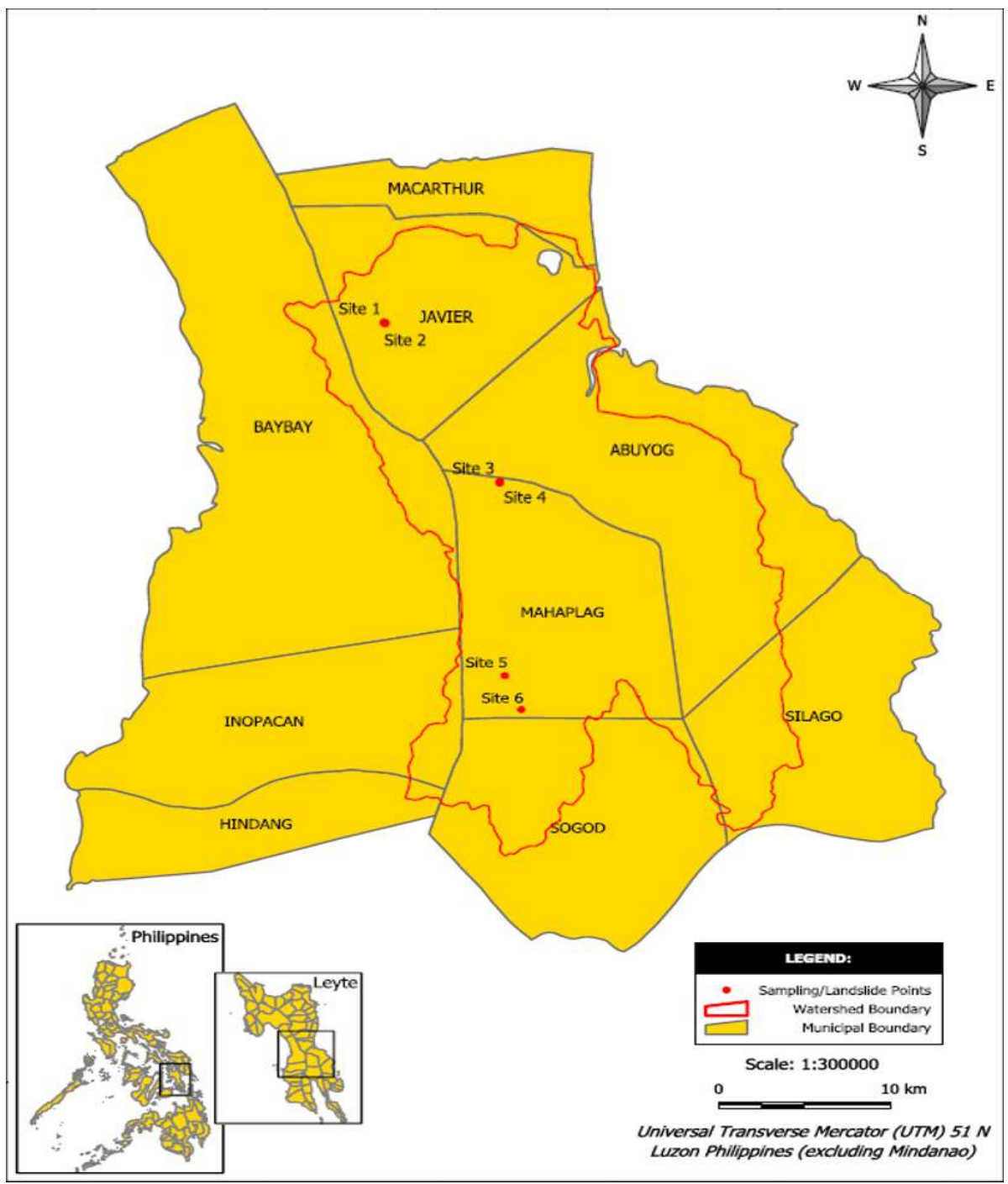

Figure 1. Map showing the extent of the Cadac-an watershed in Leyte, Philippines. Political/municipal boundary is intended for information purposes only and may have not been prepared for, or be suitable for legal, engineering or surveying purposes. Source:DA-BAR/VSU GIS Services Unit, undated 
Physical characteristics of soils in landslide areas

Figure 2 ( $\mathrm{a} \& \mathrm{~b})$ and Table 1 showed the site characteristics and soil profiles and landscape features, respectively, of the sampling sites from the landslide areas of Cadac-an watershed. Soil profiles 1 (summit) and 2 (shoulder) from Guindapunan, Javier were represented by landslide cuts. The run out distance of landslide materials is about $100-120 \mathrm{~m}$ and $20-25 \mathrm{~m}$, respectively, from the source to depositional area. The area was steep and vegetated with Cocos nucifera, Musa textilis, Musa sp., shrubs and some species from family Poaceae.

Table 1. Landscape features of the landslide areas in Cadac-an watershed in Leyte, Philippines

\begin{tabular}{|c|c|c|c|c|c|}
\hline \multirow[b]{2}{*}{ Profiles } & \multicolumn{5}{|c|}{ Site Characteristics } \\
\hline & Location & Coordinates & $\begin{array}{c}\text { Physiographic } \\
\text { Position }\end{array}$ & $\begin{array}{c}\text { Slope } \\
\text { Gradient }\end{array}$ & Vegetation \\
\hline 1 & $\begin{array}{c}\text { Guindapunan, } \\
\text { Javier } \\
\text { (landslide cut) }\end{array}$ & $\begin{array}{c}10^{\circ} 45^{\prime} 12.5^{\prime \prime} \mathrm{N} \\
124^{\circ} 53^{\prime} 31.1^{\prime \prime} \mathrm{E}\end{array}$ & Summit & Steep & $\begin{array}{l}\text { Cocos nucifera, } \\
\text { Musa textilis, Musa sp., } \\
\text { shrubs and some } \\
\text { species from family } \\
\text { Poaceae }\end{array}$ \\
\hline 2 & $\begin{array}{c}\text { Guindapunan, } \\
\text { Javier } \\
\text { (landslide cut) }\end{array}$ & $\begin{array}{l}10^{\circ} 45^{\prime} 10.4^{\prime \prime} \mathrm{N} \\
124^{\circ} 53^{\prime} 32.9^{\prime \prime} \mathrm{E}\end{array}$ & Shoulder & Steep & $\begin{array}{l}\text { Cocos nucifera, } \\
\text { Musa textilis, Musa sp., } \\
\text { shrubs and some } \\
\text { species from family } \\
\text { Poaceae }\end{array}$ \\
\hline 3 & $\begin{array}{c}\text { Balinsasayao, } \\
\text { Abuyog } \\
\text { (tension crack) }\end{array}$ & $\begin{array}{l}10^{\circ} 39^{\prime} 53.2^{\prime \prime} \mathrm{N} \\
124^{\circ} 57^{\prime} 14.8^{\prime \prime} \mathrm{E}\end{array}$ & Summit & Sloping & $\begin{array}{l}\text { Cocos nucifera, } \\
\text { Musa sp., shrubs and } \\
\text { some species from } \\
\text { family Pteridophyta } \\
\text { and Poaceae }\end{array}$ \\
\hline 4 & $\begin{array}{l}\text { Balinsasayao, } \\
\text { Abuyog } \\
\text { (landslide/road } \\
\text { cut) }\end{array}$ & $\begin{array}{l}10^{\circ} 39^{\prime} 52.6^{\prime \prime} \mathrm{N} \\
124^{\circ} 57^{\prime} 14.0^{\prime \prime} \mathrm{E}\end{array}$ & Shoulder & Sloping & $\begin{array}{l}\text { Cocos nucifera, Musa } \\
\text { sp., Manihot esculenta, } \\
\text { shrubs and some } \\
\text { species from family } \\
\text { Pteridophyta and } \\
\text { Poaceae }\end{array}$ \\
\hline 5 & $\begin{array}{c}\text { Mahayahay, } \\
\text { Mahaplag } \\
\text { (landslide/road } \\
\text { cut) }\end{array}$ & $\begin{array}{l}10^{\circ} 32^{\prime} 57.6^{\prime \prime} \mathrm{N} \\
124^{\circ} 57^{\prime} 20.9^{\prime \prime} \mathrm{E}\end{array}$ & Shoulder & $\begin{array}{l}\text { Gently } \\
\text { sloping }\end{array}$ & $\begin{array}{l}\text { Cocos nucifera, Musa } \\
\text { sp., Arachis pintoi, } \\
\text { shrubs and some } \\
\text { species from family } \\
\text { Pteridophyta and } \\
\text { Poaceae }\end{array}$ \\
\hline 6 & $\begin{array}{c}\text { Polahongon, } \\
\text { Mahaplag } \\
\text { (landslide/road } \\
\text { cut) }\end{array}$ & $\begin{array}{l}10^{\circ} 31^{\prime} 38.6^{\prime \prime} \mathrm{N} \\
124^{\circ} 57^{\prime} 51.8^{\prime \prime} \mathrm{E}\end{array}$ & Shoulder & $\begin{array}{l}\text { Gently } \\
\text { sloping }\end{array}$ & $\begin{array}{l}\text { Cocos nucifera, Musa } \\
\text { sp., Leucaena } \\
\text { leucocephala, } \\
\text { Arachis pintoi, shrubs } \\
\text { and some species from } \\
\text { family Pteridophyta } \\
\text { and Poaceae }\end{array}$ \\
\hline
\end{tabular}



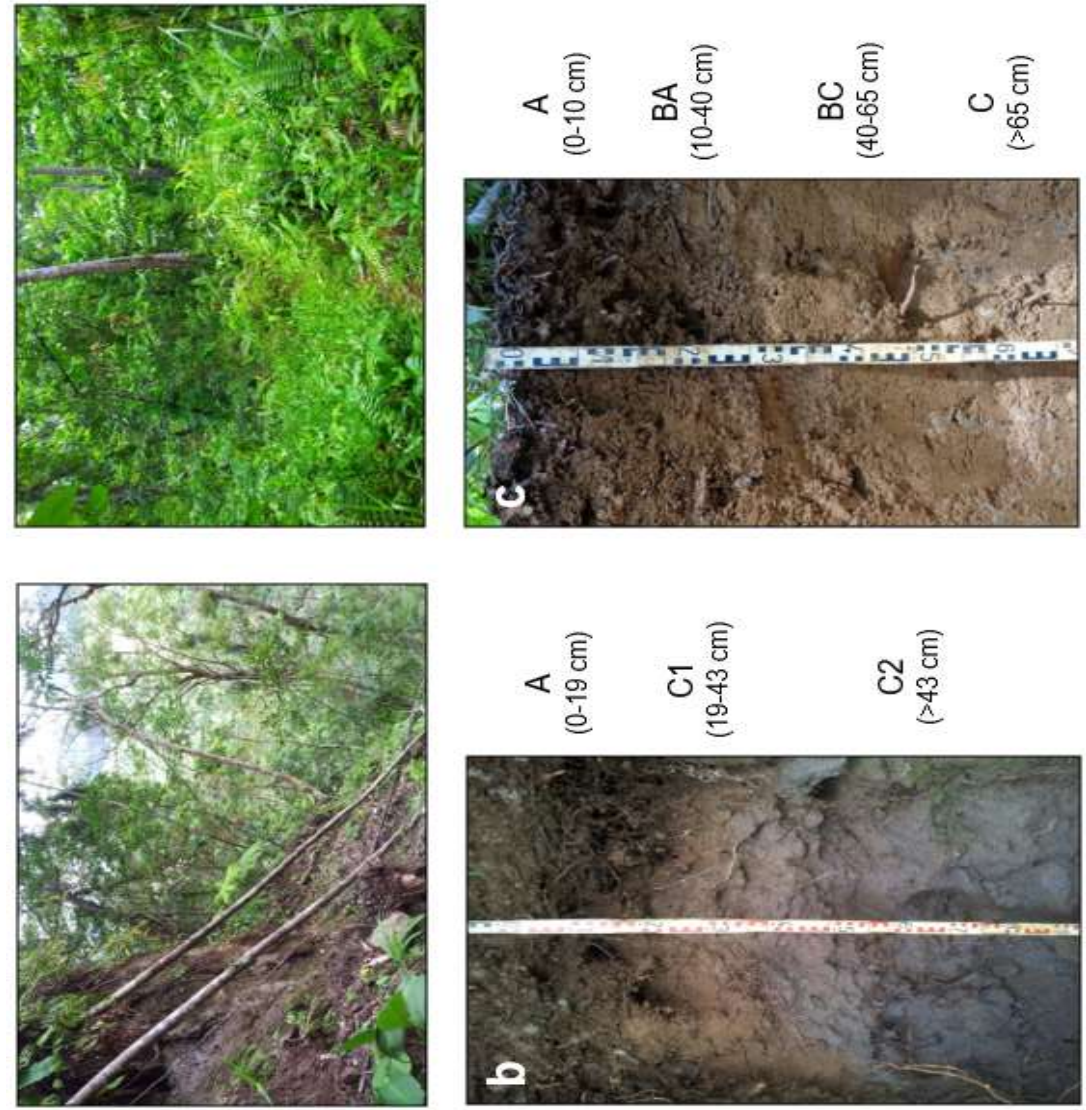

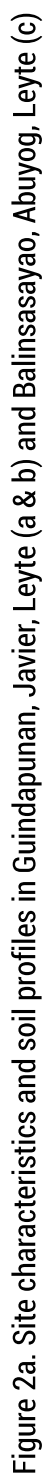



$$
\begin{aligned}
& \text { 《完 } \\
& \text { ن }
\end{aligned}
$$

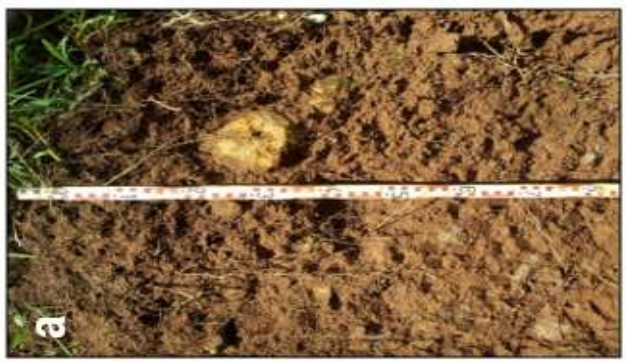


Physical characteristics of soils in landslide areas
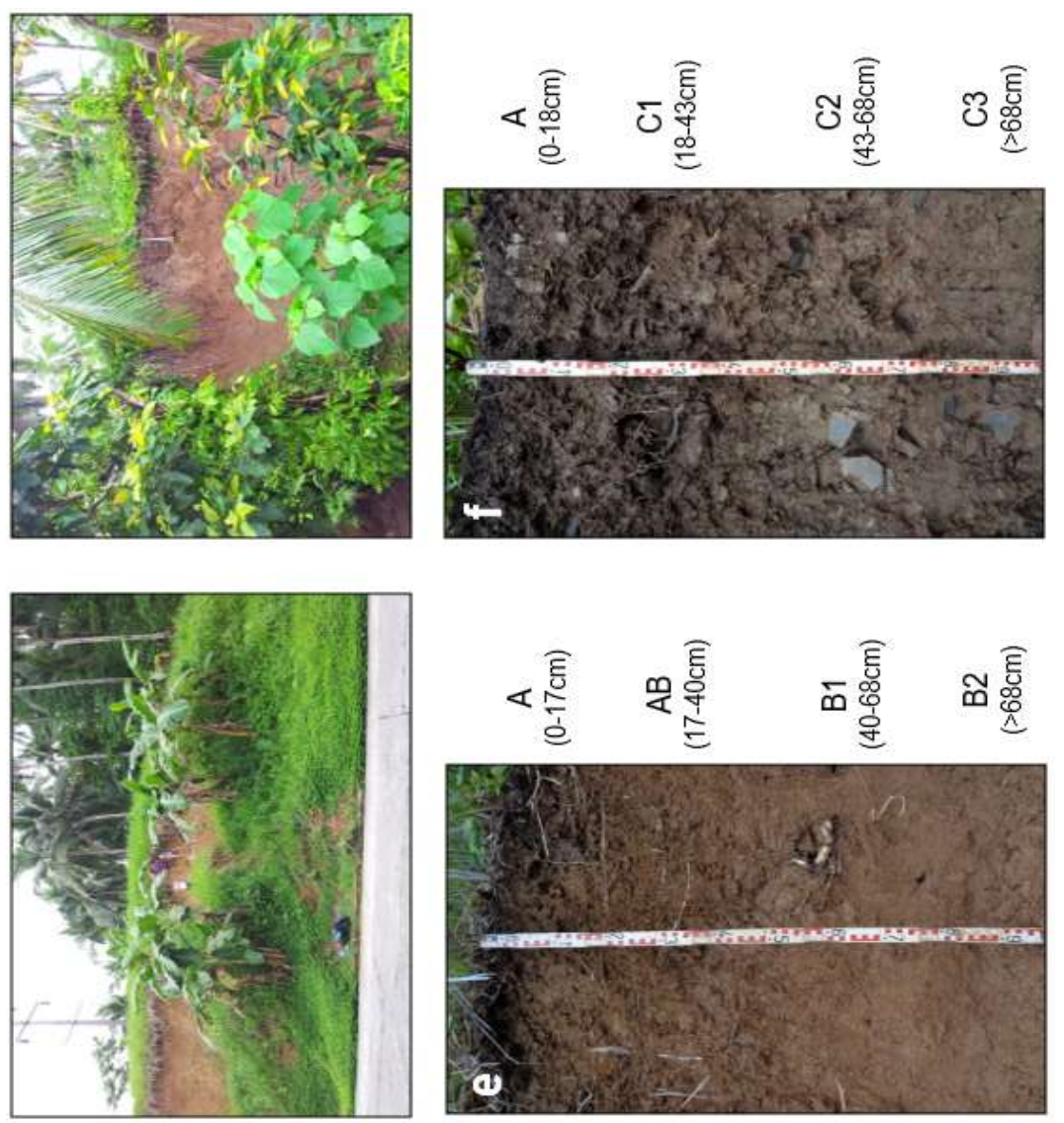


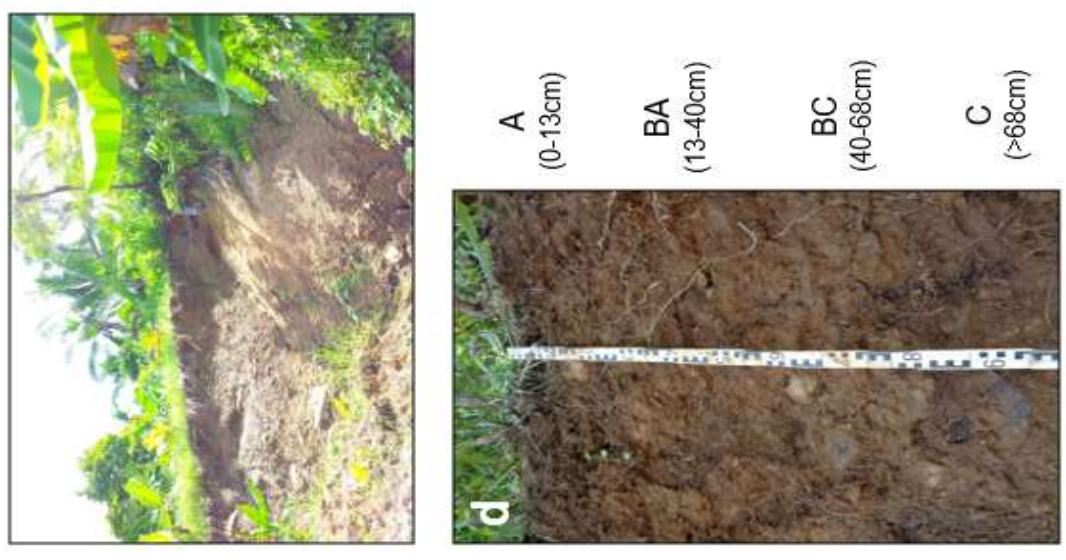
Moreover, both profiles 3 and 4 were located in Balinsasayao, Abuyog. Profile 3 (summit) was represented by a deep tension crack, measuring a depth of about 1$2 \mathrm{~m}$ and a width of about $1 \mathrm{~m}$ and extends about $10-15 \mathrm{~m}$ while profile 4 (shoulder) was represented by a road cut with a run out distance of about $20-25 \mathrm{~m}$. The areas were sloping and dominated by Cocos nucifera, Musa sp., Manihot esculenta, shrubs and some species from family Pteridophyta and Poaceae.

On the other hand, profile 5 (shoulder) from Mahayahay and profile 6 (shoulder) from Polahongon, both located in the municipality of Mahaplag, were represented by road cuts extending a run out distance of about $12-15 \mathrm{~m}$ and $10-13 \mathrm{~m}$, respectively. These areas were gently sloping and vegetated with Cocos nucifera, Musa sp., Leucaena leucocephala, Arachis pintoi, shrubs and some species from family Pteridophyta and Poaceae.

\section{Particle Size Distribution}

Particle size distribution indicates the proportion of sand, silt and clay content that determines the textural class of the soil. It is the single most important property since it is a stable characteristic of the soil which greatly affects other soil properties (Hillel 2004, Brady \& Weil 1999).

Figure 3 shows the particle size distribution of soils from the landslides areas of Cadac-an watershed. Generally, soils from the landslide areas in Cadac-an watershed had a sandy loam to clay loam to clayey texture. Results showed that soil sample from profiles 1, 3, 4 and 6 contain moderate clay (28.3-37.9\%), silt (25.0$37.0 \%$ ) and sand (29.6-44.6\%). These soils exhibited a more or less equal distribution of the three soil separates. However, soils from profile 2 were composed of low clay (10.4-15.4\%), moderate silt (17.5-30.0\%) and very high sand (54.6-77.3\%) content. The high amount of sand fractions can be due to the saprolite coming from the ophiolitic parent rock. On the other hand, soils from profile 5 were composed of high clay (42.9-47.9\%), moderate silt (24.9-27.5\%) and sand (24.6$32.1 \%$ ). The characteristic of being clayey can be attributed to the nature of its parent materials, mainly shale and andesite, which developed into fine-textured soils (Maranguit \& Asio 2013).

\section{Bulk Density}

Soil bulk density refers to the mass of soil solids per unit bulk volume, including the volume of the voids which is expressed in $\mathrm{g} \mathrm{cm}^{-3}$ (FAO 2006). It is greatly affected by the clay content and soil structure (Hillel 2004). This property is used as an index of compaction and porosity and it directly affects the root development and water, gas and solute movement in the soil.

Results of the study showed bulk density values which ranged from 1.01 to $1.38 \mathrm{~g} \mathrm{~cm}^{-3}$ (Table 2). It was observed that bulk density values of surface horizons were lower compared to subsurface horizons. This can be attributed to the considerable amount of organic matter from the leaf litters and decomposed roots. These values suggest better soil aggregation which leads to better aeration in the surface horizons compared to the subsurface horizons. On the other hand, increasing bulk density values on the subsurface horizons can be attributed to the weight of overlying layers, lower organic matter and to the presence of partially weathered and unweathered rock or parent material. The same result was observed 
Physical characteristics of soils in landslide areas

in the study of Jadina (2013), wherein bulk densities increased with depth ranging from 1.0 to $1.11 \mathrm{~g} \mathrm{~cm}^{-3}$ (Sogod) and 1.39 to $1.62 \mathrm{~g} \mathrm{~cm}^{-3}$ (San Francisco) which was attributed to relatively higher amount of organic matter in the surface compared to subsurface soil. In relation to landslide occurrences, soils having low bulk density are more prone to landslide. This can be possibly due to the high amount of moisture that can be retained by the soil as well as the weight of soil particularly in steep terrain which would move and may result in landslides.

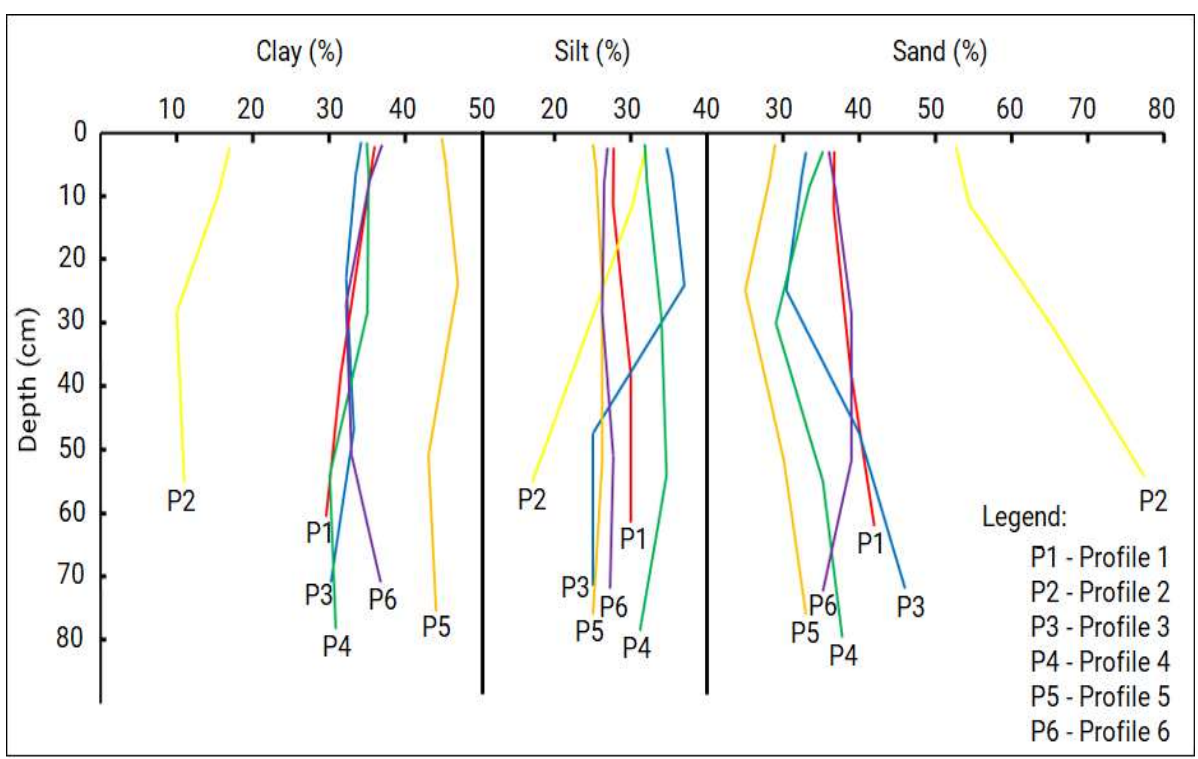

Figure 3. Particle size distribution of soils from the landslide areas of Cadac-an watershed in Leyte, Philippines

\section{Particle Density}

Soil particle density is the ratio of the total mass of soil solids to its particle volume. It plays an important role in understanding and determination of other physical properties such as bulk density and porosity. Particle density values are influenced by the mineralogy of the soil. The mean mass per unit volume of solids in most mineral soils is about 2.6 to $2.7 \mathrm{~g} \mathrm{~cm}^{-3}$, which is close to the density of quartz since it is generally the most prevalent mineral in the coarsest fraction of the soil (Hillel 2004, Freeze \& Cherry 1979). The presence of large amounts of heavy minerals such as magnetite, limonite and hematite can result in higher particle density values (Chan et al 2013).

Results showed that particle density values of the soil ranged from 2.15 to $2.56 \mathrm{~g}$ $\mathrm{cm}^{-3}$ (Table 2). The values obtained which, were lower than the average value (2.6$\left.2.7 \mathrm{~g} \mathrm{~cm}^{-3}\right)$, can be explained by the mixed minerals present in the soil. 


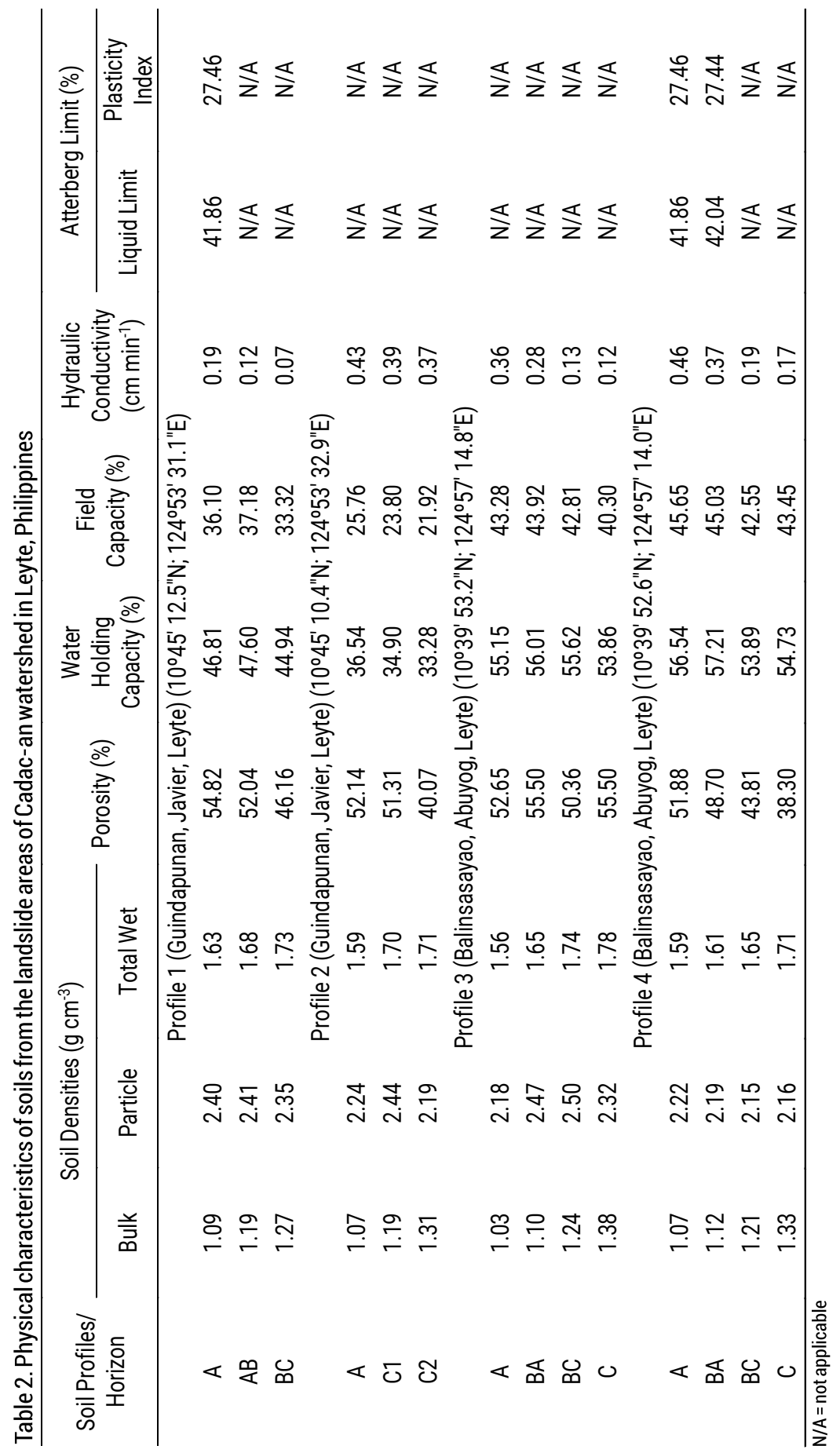


Physical characteristics of soils in landslide areas

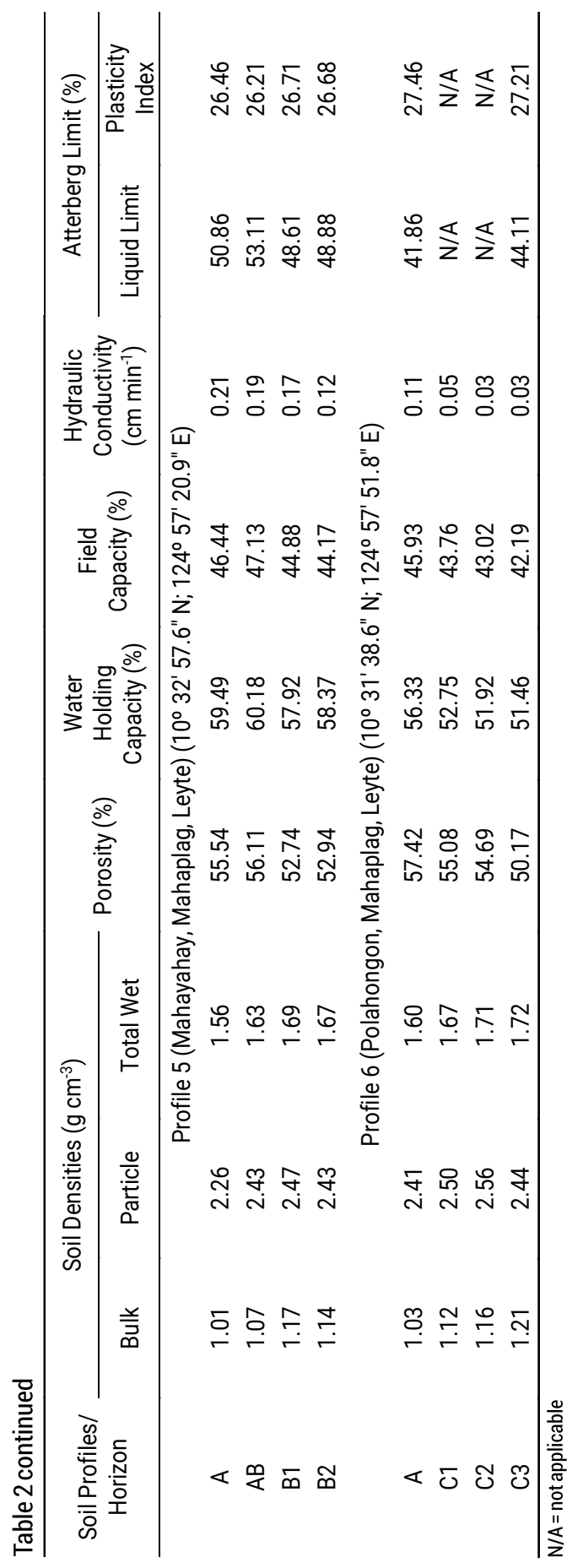




\section{Porosity}

Porosity is an index of the relative pore volume in the soil (Hillel 2004). Results showed that porosity values are relatively higher in the surface horizons than in the subsurface horizons. Porosity values ranged from 38.30 to $57.42 \%$ (Table 2 ).

The values obtained were expected since this property is correlated with the bulk density in which soils with low bulk density has high porosity and those with high bulk density, has low porosity. The higher porosity values in the surface horizon can be explained by the abundance of fine pores due to root activities and high organic matter content which can improve soil aggregation.

\section{Total Soil Wet Density}

The total soil wet density is an expression of the total mass of a saturated soil per unit bulk volume (Hillel 2004). It is an important soil physical property particularly in relation to landslide prediction studies (Pack et al 2000). Results show that the total soil wet density values observed in the research sites ranged from 1.56 to $1.78 \mathrm{~g} \mathrm{~cm}^{-3}$ (Table 2). The values obtained show that the soils could be prone to movement. The higher the total soil wet density $\left(>1.8 \mathrm{~g} \mathrm{~cm}^{-3}\right)$ values, the higher the susceptibility of the area to landslides (Jadina 2010).

\section{Water Holding Capacity and Field Capacity}

Water holding capacity is the maximum amount of water that a soil can retain at saturation, while field capacity is the amount of water in the soil after the gravitational water has drained away.

Table 2 shows the water holding and field capacities of soil samples from Cadac-an watershed. Results revealed that soil samples from profiles $1,3,4,5$ and 6 exhibited water holding capacity which ranged from 44.94 to $60.18 \%$ and field capacity which ranged from 33.32 to $47.13 \%$.

On the other hand, soil samples from profile 2 exhibited low water holding capacity (33.28-36.54\%) and field capacity (21.92-25.76\%). These values can be attributed to the low amount of clay which influenced the moisture retention of the soil. The amount of moisture retained in the soil is increased when soil is high in clay content. The same result was obtained in the study of Pathak et al (2002), where moisture retained by the soil increases with an increase in clay content.

\section{Saturated Hydraulic Conductivity}

Saturated hydraulic conductivity is a measure of the soil's ability to transmit water when subjected to a hydraulic gradient. This property is affected by soil texture, structure, bulk density, viscosity of the fluid and degree of saturation.

Results revealed that hydraulic conductivity was higher in soils with coarser texture (Table 2). Profile 2, which was composed of relatively high amount of sand fraction, exhibited higher rate of hydraulic conductivity which ranged from 0.37 to $0.46 \mathrm{~cm} \mathrm{~min}^{-1}$. This can be attributed to the dominance of macropores due to sandy textured soil, in which water tends to flow freely down the profile.

Moreover, hydraulic conductivity was high in the surface soils and decreased with depth from 0.46 to $0.03 \mathrm{~cm} \mathrm{~min}^{-1}$. This can be attributed to the increase in bulk 
Physical characteristics of soils in landslide areas

density of the soil as depth increased. A soil with low bulk density tends to have greater hydraulic conductivity since water can easily permeate through the horizon while soils with high bulk density would have low permeability, resulting to slow water movement through the horizon due to compaction (Sales et al 2014, Sauer \& Logsdon 2002).

\section{Atterberg Limit}

Liquid limit (LL) is defined as the moisture content at which soil begins to behave as a liquid material and begins to flow, while plastic limit (PL) is defined as the moisture content at which soil begins to behave as a plastic material. Soils with water content equal to and greater than that of liquid limit will tend to flow like a viscous fluid, particularly during heavy and intense rainfall which may result to landslide occurrence. Plasticity index (PI) is the difference between the liquid limit and plastic limit of a soil (Jackson 1997).

Analyses for the above parameters were done only on soil samples that contain greater than $35 \%$ of clay. Results showed that soil samples from profiles $1,4,5$ and 6 exhibited liquid limit which ranged from 41.86 to $53.11 \%$ and plastic index which ranged from 26.21 to $27.46 \%$ (Table 2 ). Interestingly, soil profiles from landslide areas will not tend to behave like a viscous fluid as its water content is less than that of liquid limit. However, it does not imply that landslides will not occur in these areas as other factors must be considered.

\section{CONCLUSIONS AND RECOMMENDATIONS}

Generally, soils from the landslide areas in Cadac-an watershed had a sandy loam to clay loam to clayey texture, low bulk density $\left(1.01-1.38 \mathrm{~g} \mathrm{~cm}^{-3}\right)$, low particle density $\left(2.15-2.56 \mathrm{~g} \mathrm{~cm}^{-3}\right)$, high porosity $(38.30-57.42 \%)$, moderate total soil wet density $\left(1.56-1.78 \mathrm{~g} \mathrm{~cm}^{-3}\right)$, moderate to high water holding capacity $(33.28-60.18 \%)$, low to moderate field capacity $(21.92-47.13 \%)$, moderately high to high saturated hydraulic conductivity $\left(0.03-0.46 \mathrm{~cm} \mathrm{~min}^{-1}\right)$, moderate liquid limit $(41.86-53.11 \%)$ and low plastic index (26.21-27.46\%). From these results, it was concluded that the soils are susceptible to landslide occurrence.

It is highly recommended to conduct constant assessment and monitoring of landslide occurrences in the area. Moreover, it is encouraged to plant more trees, prohibit tree cutting, delineate danger zones, establish more rain gauge stations and provide early warning systems to somehow prepare for the consequences brought about by landslides. A thorough and continuous study is needed to provide an efficient and effective measure to mitigate impacts of the phenomenon in the watershed areas in Leyte, Philippines.

\section{ACKNOWLEDGMENT}

The authors would like to thank the Department of Science and Technology Science Education Institute (DOST-SEI) Accelerated Science and Technology Human Resource Development Program (ASTHRDP) for the funding support. 
Cabelin \& Jadina

\section{REFERENCES}

Brady NC and Weil RR. 1999. The Nature and Properties of Soil (12th edn). PrenticeHall, London

Chan CM, Pun KH \& Ahmad F. 2013. A fundamental parametric study on the solidification of Malaysian dredged marine soils. World Applied Sciences Journal 24(6):784-793

Chen S, Chou H, Chen S, Wu C \& Lin B. 2014. Characteristics of rainfall-induced landslides in Miocene formations: A case study of the Shenmu watershed, Central Taiwan. Engineering Geology 169:133-146

Food and Agriculture Organization (FAO). 2006. Guidelines for soil description (4th edn). Rome, Italy

Freeze RA and Cherry JA.1979. Groundwater. Prentice-Hall, Englewood Cliffs, New Jersey

Hillel D. 2004. Introduction to environmental soil physics. Elsevier Academic Press, Amsterdam

International Soil Reference and Information Center (ISRIC). 1995. In Van Reuwijk LP (ed) Procedures for soil analysis. Wageningen, the Netherlands

Jackson JA. 1997. Glossary of geology (4th edn) (pp769). American Geological Institute, Alexandria

Jadina BC. 2010. GIS-aided biophysical characterization and assessment of a landscape in relation to landslide occurrences (PhD dissertation). University of the Philippines, Laguna, Philippines

Jadina BC. 2013. GIS-aided biophysical characterization of Southern Leyte landscape in relation to landslide occurrences. SEARCA Agriculture and Development Discussion Paper Series 2013(2):1-55

Klute A. 1986. Methods of soil analysis part 1: physical and mineralogical (2nd edn). Soil Science Society of America, American Society of Agronomy Inc., Madison, Wisconsin, USA

Mandal S and Maiti R. 2013. Assessing the triggering rainfall-induced landslip events in the Shivkhola watershed of Darjiling Himalaya, West Bengal. European Journal of Geology 4(3):21-37

Maranguit DS and Asio VB. 2013. Morpho-physical and chemical characteristics of mountain soils in Central Leyte. Annals of Tropical Research 35(1):35-60

National Soil Survey Center (NSSC). 1995. Soil survey laboratory information manual. Soil Survey Information Report No. 45, Version 1.0, May 1995. Soil Survey Laboratory, Lincoln, Nebraska

Pack RT, Tarboton DG \& Goodwin CN. 2000. GIS-based landslide susceptibility mapping with SINMAP. In Bay JA (ed) Proceedings of the 34th Symposium on Engineering Geology and Geotechnical Engineering (pp219-231). Idaho State University

Pathak P, Wani SP, Piara S, Sudi R \& Srinivasa R. 2002. Hydrological characterization of benchmark agricultural watersheds in India, Thailand, and Vietnam. Global Theme 3: Water, Soil, and Agrobiodiversity Management for Ecosystem Report no. 2 (pp52), Patancheru 502 324, Andhra Pradesh, India: International Crops Research Institute for the Semi-Arid Tropics

Rasul G and Thapa GB. 2007. The Impact of Policy and Institutional Environment on Costs and Benefits of Sustainable Agricultural Land Uses: The Case of the Chittagong Hill Tracts, Bangladesh. Environmental Management 40(2):237283 
Physical characteristics of soils in landslide areas

Sales EG, Almeida CDN, Farias AS \& Coelho VHR. 2014. Hydrodynamic characterization of soils within a representative watershed in northeast Brazil. Proceedings from the International Association of Hydrological Sciences 364:94-99

Sauer TJ and Logsdon SD. 2002. Hydraulic and physical properties of stony soils in a small watershed. Soil Science Society of America Journal 66(6):1947-1956

Tan CH, Ku CY, Chi SY, Chen YH, Fei LY, Lee JF \& Su TW. 2008. Assessment of regional rainfall-induced landslides using 3S-based hydro-geological model. In Chen et al (eds) Landslides and Engineered Slopes (pp1639-1645). Taylor \& Francis Group, London

Walia CS, Singh SP, Dhankar RP, Ram J, Kamble KH \& Katiyar DK. 2010. Watershed characterization and soil resource mapping for land use planning of Moolbari watershed, Shimla District, Himachal Pradesh in Lesser Himalayas. Current Science 98(2):176-183

Wani SP, Sreedevi TK, Reddy TSV, Venkateswarlu B \& Prasad CS. 2008. Community watersheds for improved livelihoods through consortium approach in drought prone rain-fed areas. Journal of Hydrological Research and Development 23:55-77 